\title{
CONCENTRATION OF THE CELL SUSPENSION IN THE WASSERMANN TEST*
}

\author{
BY \\ P. N. COLEMAN \\ From: the Friarage Hospital, Northallerton, Yorks.
}

I have been interested in the concentration of the cell suspension in the Wassermann test, because for some years I have followed the Fairbrother and Maddocks technique, using a cell concentration that is two and a half times that used in the classical Wyler Wassermann. There are, in fact, considerable differences in the concentration recommended for the cell suspension in the various well-established techniques. Thus Kolmer (1939), Eagle (1939), Price and Wilkinson (1947), Wadsworth (1947) and Fairbrother (1942) recommended concentrations of $0.3,0.6,0.6,1.0$, and 1.5 per cent. respectively (expressed as the final concentration of packed cells). Periods recommended for haemolysis were 60,20 to $30,30,15$, and $60 \mathrm{~min}$., followed by overnight sedimentation of the cells. All the methods give reliable results and it is considered below how this fact can be reconciled with the diversity of the conditions recommended for the operation of the haemolytic system. The type of haemolytic system that might be most suitable for particular circumstances is also examined. Attention has been directed to cell concentration and time of haemolysis ; amboceptor dose and the effects of variations between individual batches of cells and of adding formalin to the cells have been dealt with in a previous paper (Coleman, 1952).

\section{Experiments}

The details of the experimental titrations carried out followed in general the methods described in the previous paper. Representative results are shown in Figs 1 and 2 and the Table (overleaf). Additional experimental data will be referred to in the discussion. A strong sensitized cell suspension was prepared corresponding to a final concentration of cells in the various titrations of 1.5 per cent. expressed in terms of packed cells per cent. (Unsensitized cell suspension adjusted to $\mathrm{Hb}$ content of 15 per cent. Haldane.) Weaker suspensions were obtained

* Received for publication March 5, 1954 by dilution. Complement is recorded in units equivalent to 1,000 times the reciprocal of the dilution of guineapig serum in the standard volume. For the Wassermann titrations shown in the Table, pooled positive serum was adjusted to a suitable reagin content by dilution with normal serum on the results of a preliminary titration. The reagin content of this composite serum was taken to be 10 arbitrary units, and further dilutions in normal serum containing from 1 to 9 units were then prepared. The tests were read after one hour of haemolysis and again after overnight sedimentation of the cells in the refrigerator. Tubes in which there was partial haemolysis were compared visually with a set of standards showing various degrees of haemolysis. To prepare these standards, the supernatant fluid from tubes showing complete inhibition was mixed in appropriate proportions with the contents of tubes showing complete haemolysis.

\section{Discussion}

Fig. 1 indicates that a long period of haemolysis is to be preferred. If the tests are read after one hour, haemolysis is virtually complete and the time of reading is not critical. The sensitivity in detection of low reagin sera in the test proper will not be reduced if the complement titration is read after a similar long period of haemolysis. Eagle (1937a) condemns the practice of reading tests after overnight sedimentation of the cells, stating that additional haemolysis occurs during sedimentation and that the tests are thereby rendered insensitive. This additional haemolysis does not occur when a period of one hour is allowed for haemolysis, and the results both of the test proper and of the complement titration have been found to be essentially the same whether read at one hour or after overnight sedimentation of the cells. It is of interest that Kolmer, who employs a long period of haemolysis, allows sedimentation of the cells.

Because complement is more effective in a more concentrated solution (Eagle, 1937b), the amount of complement required to bring about 50 per cent. 
TABLE

TITRATION OF POSITIVE SERUM USING VARIOUS CELL CONCENTRATIONS

\begin{tabular}{|c|c|c|c|c|c|c|c|c|c|c|c|c|c|c|}
\hline \multirow{2}{*}{$\begin{array}{c}\text { Final } \\
\text { Concentration } \\
\text { of Cells } \\
\text { (per cent.) }\end{array}$} & \multicolumn{2}{|c|}{$\begin{array}{l}\text { Complement } \\
\text { at Fixation Stage }\end{array}$} & \multirow[b]{2}{*}{10} & \multicolumn{6}{|c|}{$\begin{array}{c}\text { Result of Test Proper } \\
\text { (Reagin Range } 1-10 \text { units) }\end{array}$} & \multirow[b]{2}{*}{3} & \multirow[b]{2}{*}{2} & \multirow[b]{2}{*}{1} & \multirow{2}{*}{$\begin{array}{l}\text { Positive } \\
\text { Serum } \\
\text { Control* }\end{array}$} & \multirow{2}{*}{$\begin{array}{c}\text { Normal } \\
\text { Serum } \\
\text { Control } †\end{array}$} \\
\hline & M.H.D. & Units & & 9 & 8 & 7 & 6 & 5 & 4 & & & & & \\
\hline \multirow{5}{*}{0.38} & $1 \cdot 5$ & 12 & + & + & + & + & + & + & + & + & 10 & 40 & 80 & 80 \\
\hline & $2 \cdot 0$ & 16 & + & + & + & + & + & + & + & + & 10 & 60 & 95 & 95 \\
\hline & $2 \cdot 5$ & 20 & + & + & + & + & + & + & + & 10 & 90 & - & - & - \\
\hline & 3.0 & 25 & + & + & + & + & + & + & + & 15 & 90 & - & - & - \\
\hline & $5 \cdot 0$ & 41 & + & + & + & + & 10 & 80 & 95 & - & - & - & - & - \\
\hline \multirow{5}{*}{0.75} & $1 \cdot 5$ & 19 & + & + & + & + & + & + & + & 20 & 60 & 80 & 95 & 95 \\
\hline & $2 \cdot 0$ & 26 & + & + & + & + & + & + & 15 & 40 & 80 & - & - & - \\
\hline & $2 \cdot 5$ & 32 & + & + & + & + & + & 20 & 40 & 60 & 80 & - & - & - \\
\hline & $3 \cdot 0$ & 39 & + & + & + & + & 10 & 30 & 80 & 90 & - & - & - & - \\
\hline & $5 \cdot 0$ & 65 & + & + & 15 & 35 & 60 & 80 & - & - & - & - & - & - \\
\hline \multirow{4}{*}{$1 \cdot 13$} & 1.5 & 24 & + & + & + & + & + & 10 & 25 & 40 & 60 & 90 & 95 & 95 \\
\hline & $2 \cdot 0$ & 32 & + & + & + & + & + & 20 & 40 & 60 & 90 & - & - & - \\
\hline & $2 \cdot 5$ & 40 & + & + & + & + & 10 & 30 & 60 & 80 & 90 & - & - & - \\
\hline & $3 \cdot 0$ & 48 & + & + & + & 6 & 20 & 50 & 80 & 90 & - & - & - & - \\
\hline \multirow{4}{*}{$1 \cdot 50$} & $1 \cdot 5$ & 27 & + & + & + & + & 10 & 20 & 30 & 40 & 80 & 85 & 95 & 95 \\
\hline & $2 \cdot 0$ & 37 & + & + & + & + & 15 & 25 & 40 & 70 & 95 & - & - & - \\
\hline & $2 \cdot 5$ & 46 & + & + & + & 15 & 25 & 40 & 60 & 80 & 95 & - & - & - \\
\hline & $3 \cdot 0$ & 55 & + & + & 15 & 20 & 40 & 60 & 80 & 90 & - & - & - & - \\
\hline
\end{tabular}

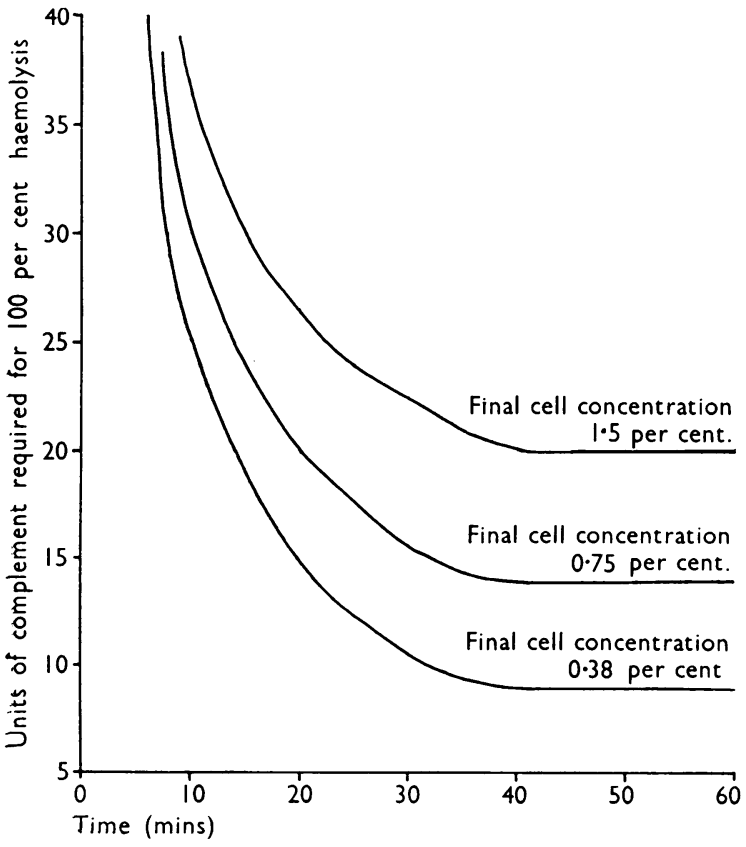

FIG. 1

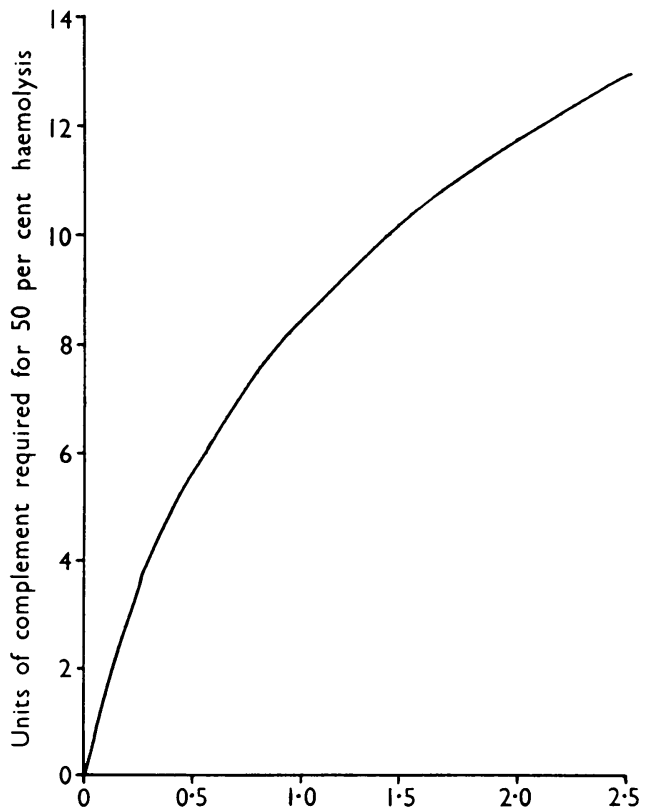

Final concentration of cell suspension

Fig. 2 
haemolysis is not directly proportional to the cell concentration. Fig. 2 shows that a four-fold increase in the cell concentration only requires that the complement concentration be doubled. The effect of changes in cell concentration on the results of the test proper is not therefore as great as might at first be expected.

The effect of changes of cell concentration on the test proper is shown in the Table. Using in each case a complement dose at the fixation stage that is optimum for sensitivity,* a roughly equal sensitivity is obtained at all cell concentrations. However, the range of reagin content covered by the change from the negative reaction to the complete inhibition of haemolysis increases with the cell concentration. Using a single " diagnostic" tube in the test proper, more information is therefore obtained concerning the reagin content of a serum when more concentrated cell suspensions are employed. In the Table, using the weakest cell suspension, all sera having a reagin content of 3 units or over are reported indifferently as positive, whereas using the strongest cell suspension, full information is obtained on sera with reagin contents 2 to 6 units, 7 units or over being reported as positive. Adding an additional " quantitative" tube (containing 5 MHD of complement) when using the weakest cells, enables sera of reagin content 2 to 6 to be distinguished, 7 units or over being reported as strong positive. This information is no more than that obtained by a single tube using the more concentrated cells. In an additional experiment, dilutions of a strongly positive serum in saline were titrated using a fixed dose of complement ( 3 MHD for the particular cells to be used at the haemolysis stage). Parallel titration using four strengths of cells were set up. Taking the end-point as complete inhibition of haemolysis after overnight sedimentation, titres of one sixty-forth, one thirty-second, one sixteenth, and one eighth were obtained, seven tubes being required to obtain the end-point using the weakest cells, four tubes using the strongest.

The increased information concerning the reagin content obtained when using a strong cell suspension to some extent disappears if the tests are read at one hour, on removing racks from the $37^{\circ} \mathrm{C}$. bath.

* For maximum sensitivity the complement dose at the fixation stage should be just greater than the minimum amount required to bring about complete haemolysis after pre-incubation of complement as for the test proper with normal serum and antigen (Price, 1949). Consideration of the normal serum control tubes of the titrations shown in the Table indicates that maximum sensitivity is obtained in the titrations shown in Row 3 in the case of 0.38 per cent. cells and Row 2 in the case of 0.75 per cent., 1.13 per cent., and 1.5 per cent. cells.
Degrees of partial haemolysis of up to 50 per cent. are apt to be indistinguishable from complete inhibition when tubes are examined with the cells suspended, and this difficulty increases with increasing cell concentration. The statement that equal sensitivity was obtained for all concentrations of cells also requires qualifications. The lowest reagin serum in the experimental titration succeeded in producing a small but quite definite degree of inhibition of haemolysis with all four cell concentrations used, but the relative degree of inhibition was greatest with the weakest cells. In routine practice there is a wise tendency to read a test as negative unless there is a fairly appreciable degree of inhibition of haemolysis. The sharper change from negative to positive seen in titrations carried out with weak cells favours, therefore, a more sensitive test.

\section{Summary}

(1) The effect of variations of the cell concentration and the time of haemolysis on the results of the Wassermann test has been investigated. Wide variations produce relatively small effects upon the test.

(2) A long period of haemolysis is to be preferred and will permit, if it is so desired, tests to be read after overnight sedimentation of the cells without loss of sensitivity.

(3) If only one diagnostic tube is allowed for each serum tested, more information will be obtained concerning reagin content using a strong cell suspension, provided that tests are read after sedimentation of the cells. There is no serious loss of sensitivity when a strong suspension is employed.

(4) If there is no objection to increasing the number of tubes allocated to individual sera, and it is desired to read the tests on the same day as they are performed, weak cell suspensions are to be preferred. With weak cells the highest possible degree of sensitivity will be obtained.

\section{REFERENCES}

Coleman, P. N. (1952). British Journal of Venereal Diseases, 28, 129 Eagle, H. (1937a). "The Laboratory Diagnosis of Syphilis ", p. 105. Mosby, St. Louis.

(1937b). Ibid., p. 106.

- (1939). Vener. Dis. Inform., Suppl. 9, pp. 3, 155.

Fairbrother, R. W. (1942). "A Text Book of Bacteriology", 4th ed., p. 450. Heinemann, London.

Kolmer, J. A. (1939). Vener. Dis. Inform., Suppl. 9, pp. 17, 207.

Price, I. N. O. (1949). British Journal of Venereal Diseases, 25, 157. -, and Wilkinson, A. E. (1947). Ibid., 23, 124.

Wadsworth, A. B. (1947). "Standard Methods of the Division of Laboratories and Research of the New York State Department of Health ", 3rd ed., p. 375. Baillière, Tindall, and Cox, London. 